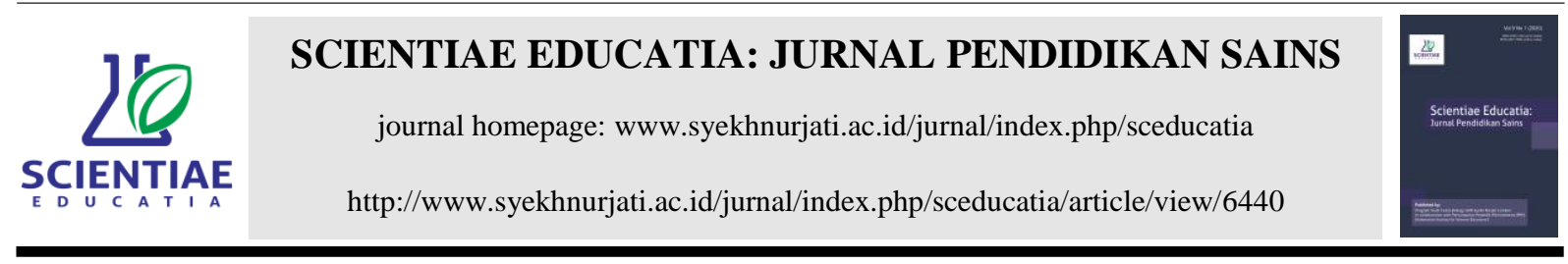

\title{
Developing STEM-Based Student Worksheet to Improve Students' Creativity and Motivation of Learning Science
}

\author{
Emi Fitrya Husna ${ }^{\mathrm{a}}$, Muhammad Adlim ${ }^{\mathrm{b}}$, Abdul Gani ${ }^{\mathrm{b}}$, Muhammad Syukric, Muhammad Iqbal ${ }^{\mathrm{d}}$ \\ ${ }^{a}$ Master of Science Education Department, Syiah Kuala University, Banda Aceh, Indonesia \\ ${ }^{b}$ Chemistry Department, Faculty of Teacher Training and Education, Syiah Kuala University, Banda Aceh, Indonesia \\ 'Physics Department, Faculty of Teacher Training and Education, Syiah Kuala University, Banda Aceh, Indonesia \\ dindonesian Language Department, Faculty of Teacher Training and Education, Syiah Kuala University, Banda Aceh, Indonesia
}

*Corresponding Author: J1 Tgk Chik Pante Kulu, Darussalam, Kec. Syiah Kuala, Banda Aceh, Aceh (NAD) 23111, Indonesia. E-mail addresses: aganihaji@unsyiah.ac.id

\begin{tabular}{|c|c|}
\hline a $r$ t $\mathbf{c}$ l e i n fo & a b s t r a c t \\
\hline $\begin{array}{l}\text { Article history: } \\
\text { Received: } 07 \text { May } 2020 \\
\text { Received in revised form: } 18 \text { May } \\
2020 \\
\text { Accepted: } 31 \text { May } 2020 \\
\text { Available online: } 30 \text { June } 2020 \\
\text { Keywords: } \\
\text { Student worksheet } \\
\text { STEM } \\
\text { Sunlight-collecting mirror } \\
\text { Science learning motivation } \\
\text { Creativity }\end{array}$ & $\begin{array}{l}\text { The Student worksheet based on science, technology, engineering, and mathematics (STEM) } \\
\text { has been prepared, validated, and tested on students at SMAN } 5 \text { Banda Aceh. The worksheet } \\
\text { guided the students to design a salt-making tool with a sunlight-gathering mirror. The } \\
\text { worksheet was developed using the ADDIE model of the research and development (R\&D) } \\
\text { method. The subjects of the study consisted of } 31 \text { students divided into some groups } \\
\text { consisting of } 6 \text { participants for each. The students were given problems and examples of salt- } \\
\text { producing tools using a sunlight-collecting mirror. The purpose of this activity was to let } \\
\text { them observe and modify according to their creativity. Based on the assessment of the tool } \\
\text { model produced by students, the gained score reached an average score of } 91 \text { (very good). } \\
\text { After the learning process, the learning outcomes increased with an average of } 42 \text { to } 70 \text {. The } \\
\text { science learning motivation and creativity scores of the students after the implementation } \\
\text { reached } 76 \text { (good) and } 79 \text { (good). }\end{array}$ \\
\hline
\end{tabular}

\section{Introduction}

On the one hand, the active role of students during the learning process is a prominent issue in implementing the Indonesian national curriculum of the 2013 Curriculum as conceptually, well known as Kurikulum 2013 (K-13). On the other hand, teachers should step in being planners and facilitators of the learning process (Ariani et al., 2019). Active learning consists of various models. One of those is an integrated approach popularly known as Science, Technology, Engineering, and Mathematics (STEM) (Adlim et al., 2018; Mahyuna et al., 2018). The STEM-based learning enhances students to get more active through integrating several disciplines which require students to be aware of technology, innovation, and problem-solving skills (Susanti et al., 2018). In short, STEM learning modules are still limited. However, those existing modules have started to be developed and have been generally tested in science classes of senior high school (Sari et al., 2018; Adlim et al., 2015)

The STEM-based learning approach is multi-disciplinary and often linked to the innovation of creating a new product. Therefore, its implementation is going to be more 
flexible in applying in the class of Entrepreneurship as popularly known in Indonesian as Prakarya dan Kewirausahaan ( $P K W U)$, than in a science class. It is because the STEM-based learning approach does not focus on mastering the concept but on creating innovative products. STEM-based learning is often closely linked to the phenomena that occur in daily life. Under the framework of the STEM-based learning settings, a science lesson can integrate chemistry and physics into one learning process. Chemistry is needed to understand the process of producing salt, while physics helps understand the characteristic of light and the use of concave mirrors. However, those kinds of subject matters will be compiled inside of the student worksheet, which will be designed by involving the engineering process in the entrepreneurship class.

Entrepreneurship subject is a vocational lesson that is intended to develop students' knowledge, attitudes, work skills, and life skills based on art, technology, and economics. Moreover, this subject is essential to train students to improve their creativity and to express their ideas. However, the need analysis and observation conducted at SMAN 5 Banda Aceh, shows that the teachers have not implemented STEM-based learning in guiding students to be innovative yet. The student worksheet, as well as other supporting learning documents, have never been used. Hence, this causes students to be unskilled neither in the classroom nor in daily life. However, as mentioned earlier, the entrepreneurship subject is supposed to develop students' life skills in learning science. An interesting subject and learning matters can significantly encourage students to be more interested in learning (Putri et al., 2018). The expected competency of the entrepreneurship subject is expected to prepare students with the competence of carrying out economic-productive activities in the workforce (Purbaningrum, 2016). So, that students' learning motivation and creativity should be improved during the entrepreneurship subject at school.

Students' learning motivation and curiosity should be endeavoured to increase students' learning engagement and creativity during the entrepreneurship class at schools. A less-varied learning process will lead students to get bored quickly. Therefore, various learning approaches which are appropriately selected can increase student creativity and learning motivation (Hasan et al., 2019). In other words, implementing a learning strategy like STEMbased learning that has never been done before may increase students' learning motivation (Kurniawan, 2017). 
Learning motivation is one of the prominent factors affecting students learning achievement. It is because high learning motivation will lead them to concentrate fully and to more actively engage in the learning process (Sari et al., 2016). Therefore, the implementation of interesting learning models is essential to increase students' learning motivation (Setiawan and Indriwati, 2018). Some suggested learning methods can be Problem-based learning or structured-project, which can enhance students' creativity to create their new idea (Mukhlis, 2017). Thus, the STEM approach is expected to encourage students to be more active and creative during the learning process, as this approach involves students to solve real problems by creating products accordingly.

STEM-based learning has been continuously developed to prepare students to be scientific societies who are advanced in technology (Saptarani et al., 2019). In their research Khoiriyah et al. (2018) confirm that STEM-based learning can promote students' thinking skills compared to the conventional learning approach. Likewise, Ariani et al. (2019), found that the STEM approach implementation can encourage students' creative thinking abilities properly. Moreover, Susanti et al. (2018) state that the students who used to learn under conventional methods show a significant improvement of their significant competencies (cognitive, affective, and psychomotor) after participating in STEM-based learning settings. Lastly, Mustain and Herlina (2019) discussed that STEM-based learning provides an improvement and good cognitive aspects proven by the increasing post-test score on average.

One of the current popular STEM-based projects is the process of producing salt made of seawater. Indonesia is the largest archipelago in the world where approximately $5,193,252$ $\mathrm{km}^{2}$ in total. It is about two-thirds of its territory is the ocean, which is around $3,288,683 \mathrm{~km}^{2}$ (Chadarisman et al., 2012). Seawater contains several types of dissolved substances such as salts which is on average $3-4.5 \%$. In their research, Trikobery et al. (2017) stated that the use of unlimited seawater has a pretty good business prospect. Besides, it also can provide jobs for coastal communities by processing it into salt. That is economical as it can be utilized for food, chemicals, or preservatives. Similarly, Maulana et al. (2017) explain that salt is one of the chemicals used by humans for their daily consumption. Salt mostly contains sodium chloride as the main element.

The salt-producing process in Indonesia generally uses the evaporation of seawater method assisted by sunlight. Therefore, it is necessary to combine both chemical and physical concepts of science under the framework of STEM together into the initiated student 
worksheet by providing students with a salt-producing project. It is also supported by making an innovative product that utilizes the principle of light reflection in a concave mirror to direct the sunlight toward a focal point. It is to accelerate the process of heating the seawater used in this salt production. Therefore, students can access information quickly and can design a technology-based tool used to turn the seawater into salt by utilizing a sunlight-collecting mirror. The novelty of this research is to design a model of salt-producing tools by using the STEM approach that elaborates the principles of science, technology, engineering, and mathematics. It helps not only students but also the community to be motivated and creative to create innovative technology products that are effective, simple, practical, and economical.

\section{Method}

The concept of the ADDIE instructional model was used in this research and development (R\&D) to guide students in creating a salt-producing tool model with a sunlight-collecting mirror. The development of the STEM-based student worksheet on the entrepreneurship lesson was expected to increase students' creativity and motivation in learning science.

This STEM-based research was conducted at Senior High School No. 5 of Banda Aceh (Known as SMAN 5 Banda Aceh), located in Hamzah Fansuri Rd, Kopelma Darussalam, Syiah Kuala, Banda Aceh. It was conducted on February $26^{\text {th }}$ to March $4^{\text {th }}, 2020$. The participants of this study were all science students of grade X at SMAN 5 Banda Aceh. They were divided into five classes. The random sampling design was selected in this study. The 31 students were studying on grade 10 science class No. 1 (X IPA 1). This sampling technique was aimed at providing equal opportunities for each member of the groups to be selected.

The study design was using a one-experimental class to be taught using the STEM-based student worksheet that had previously been developed. Students were divided into five groups to participate in the learning activity set by the teacher actively. Besides, the teacher also made sure that each group consisted of students with different abilities evenly. The different classification of group members was intended to create collaboration and help each other in solving the problems provided in the STEM-based student worksheet during the learning process.

At the first meeting of the implementation of the STEM-based student worksheet, the process of collecting data was conducted according to the steps of the STEM-based student worksheet. Then the next step was a designing process of the salt-producing tool assisted by a 
sunlight-collecting mirror. At this second stage, the students completed the design of the tool mode based on the Figures which had been drawn at the first meeting according to their creativities.

Another essential part of this research is the assessment instrument which includes the pretest and post-test questions. The science learning motivation questionnaire was adapted from Glynn et al. (2009). Afterwards, the creativity questionnaire was adapted from the research instruments of Cuenca et al. (2016), and the product evaluation questionnaire was developed based on the product assessment on the national syllabus of the entrepreneurship subjects. Lastly, the questionnaire for the student and teacher responses was constructed by the researchers. The results of the data obtained during further research were processed and analyzed using the percentage formula.

\section{Result and Discussion}

\section{The Development of the STEM-based Student Worksheet}

ADDIE model (analysis, design, development, implementation, and evaluation) was adopted to develop the current STEM-based student worksheet. The needs analysis phase was carried out to obtain information about the entrepreneurship lesson that had been implemented at school. The research location was chosen based on a preliminary study that had been conducted at SMAN 5 Banda Aceh. A needs analysis was conducted by distributing questionnaires to the teachers. The obtained data indicated that the teacher needed innovative teaching material such as a student worksheet. It was intended to develop students' creativity and science learning motivation. Besides, it was also because the student worksheet had never been implemented in this entrepreneurship class.

After conducting the needs analysis, the next phase right is the process of designing the products. At this stage, the researchers composed the STEM-based student worksheet. There were several tasks students should do based on the student worksheet including collecting the data related to the salt production assisted by sunlight, finding new ideas, designing the tool, creating the tool that had previously been drawn, and predicting the amount of produced salt as well as its.

Rahmiza et al. (2015) in their research stated that the STEM-based student worksheet is used as an alternative and effective way to make students get more enthusiastic in participating and involving themselves in the learning process. Similarly, Yulianti et al. 
(2018) that the engineering process in STEM-based learning allows students to do careful observations or investigations to design an experiment according to the generated ideas to achieve broader scientific concepts.

The development phase began with the instrument-validating process by involving four experts. Those experts are from the Chemistry Department, Physics Department, and Indonesian Language Department of Faculty of Teacher Training and Education, Syiah Kuala University, Banda Aceh. Meanwhile, the STEM-based student worksheet was assessed based on several criteria covering the teaching material, learning components, presentation method, language, physical appearance, illustrations, and complete components. Meanwhile, a validating instrument was adapted from Badan Standar Nasional Pendidikan (BNSP) or National Education Standards Agency with a slight modification. The modification of the validating instrument was done according to the characteristics of the STEM-based student worksheet that was developed by researchers. The validity of the student worksheet scored by the experts gave some raising inputs. The results obtained are then presented in Table 1.

Table 1. Student Worksheet Validity by Experts

\begin{tabular}{cccc}
\hline No & Assessment aspects & Validation result (\%) & Explanation \\
\hline 1 & Material & 100 & Valid with revision \\
2 & Learning component & 89 & Valid with revision \\
3 & Presentation & 100 & Valid with revision \\
4 & Language & 100 & Valid with revision \\
5 & Physical appearance & 97 & Valid with revision \\
6 & Illustration/ Pictures & 83 & Valid with revision \\
7 & Component completion & 100 & Valid with revision \\
& Average & 96 & \\
\hline
\end{tabular}

The data presented in Table 1 illustrates that the STEM-based student worksheet is worth applying in the entrepreneurship learning process in which the average percentage is 96 . It was then categorized into very feasible. It was because the STEM-based student worksheet instructed the students to run a model project for salt production using a sunlight-collect mirror. Arikunto (2013) states that a student worksheet with a score range of $81-100 \%$ belongs to a very feasible category. Then, the development of the student worksheet can furtherly be used in trials.

Experts then also appraised that the developed student worksheet to have good quality. It was considered as worthing applying in the learning process as it had good criteria. Rahmiza et al. (2015) mention that the learning effectiveness of students can be triggered using a 
student worksheet. Then, it could encourage students to optimize their five senses so that the learning process would be more effective.

The STEM-based skills provided in the student worksheet included conducting observations related to the given topic; finding new ideas to create a technology product - $\mathrm{a}$ salt-producing tool assisted by a sunlight-collecting mirror; being innovative in designing/drawing tools in accordance with new ideas that are being developed; developing creativity by producing a tool model according to the previous drawing design; then predicting the social values that can be generated regarding the amount of salt produced and its selling price.

The fourth stage was the implementation of the validated STEM-based student worksheet students. The implementation was only limited to SMAN 5 Banda Aceh. It was conducted from February 2020-March 2020, and it had a 2-meeting intervention with 31 participants (21 females and ten males).

The students' activities during the first meeting were: (1) having pre-test before the learning process begins, (2) grouping with members of the assigned group, (3) receiving the STEM-based student worksheet distributed in each group, (4) listening to the teacher's instruction and carefully observing the material as well as drawings through the printed materials given by researchers, (5) reading the STEM-based student worksheet (6) discussing ideas about the model of salt-producing tool assisted by a sunlight-collecting mirror, and finally (7) designing tools based on their own generated ideas. Then the activities undertaken by students at the second meeting were: (1) making a model of tools that had been designed at the first meeting according to their creativity, (2) presenting the results of the product that has been created, (3) doing a post-test, (4) filling out the questionnaire about their science learning motivation and the questionnaire regarding the STEM-based student worksheet.

The expected competence through implementing the STEM-based student worksheet could develop skills regarding the design and model of salt-producing tool assisted by a sunlightcollecting mirror. It was then expected to increase students' creativity and learning motivation in science class. While some learning objectives through the STEM-based student worksheet development were as follows, (1) students were able to design and make the salt-producing tools with a sunlight-collecting mirror based on their creativity. (2) students' designed products were useful for the production of salt and freshwater. (3) Students were able to make a model of salt-producing tool assisted by a sunlight-collecting mirror based on their 
previously designed models. However, Ariani et al. (2019) in their research strengthened that learning through the STEM approach by using discussion learning techniques can maximize the students' learning ability and motivate them to be more active in solving the surrounding problems as well as exploring their knowledge.

Therefore, it is expected that the entrepreneurship lesson using the STEM-based student worksheet can integrate several disciplines during the learning process at once. For further details, the students' activities can be seen in the Figures of Figure 1.


Figure 1. Student activity during the learning process through the STEM-based student worksheet

The last phase was evaluating the whole series of the learning processes. The evaluation was conducted by analyzing the science learning motivation and creativity of the students. Furthermore, the evaluation was analyzed based on the results of the analysis in each questionnaire, the learning outcomes from the pre-test and post-test scores, and the assessment of the created salt-producing tool assisted by a sunlight-collecting mirror as a significant product of the STEM-based student worksheet in the entrepreneurship class.

However, the STEM-based student worksheet overall had both strengths and weaknesses. In terms of strengths, this STEM-based student worksheet which was systematically developed in the entrepreneurship lesson could enable students to develop and apply their knowledge, to understand the learning materials deeply, to develop creative thinking skills, to trigger the emergence of science learning motivation and curiosity, to provide an opportunity to elaborate the concepts based on problem-solving aspects, to broaden the opportunity to practice designing an innovative product. Otherwise, the weakness of the STEM-based student worksheet was found that its implementation did not include the product marketing process. It was only intended to observe students' motivation and creativity throughout designing and creating a salt-producing tool using the sunlight-collecting mirror.

In their research, Quang et al. (2015) explain that the STEM-based student worksheet and regular student worksheets have similar components. For instance, the similar components 
include titles, study instructions, Basic Competencies, learning materials, supporting information, exposure to content, assignments/projects. However, the difference is that the STEM-based student worksheet contained the integrated knowledge of science, technology, engineering, and mathematics.

\section{Assessment of Students' Motivation for Learning Science}

The STEM-based student worksheet assessment is a teaching material that is developed based on contextual needs. It was aimed at increasing students' motivation to learn science. The assessment questionnaire was required to measure students' motivation levels in learning science. That instrument was adapted from a related study by Glynn et al. (2009), and it consisted of 30 statements that were briefly written through rating scales 1 to 5 .

Students filled questionnaires based on their experience regarding the entrepreneurship lesson using the STEM-based student worksheet. It was responded in accordance with their respective or opinion. Further, the results of the students' learning motivation questionnaire can be seen in Figure 2.

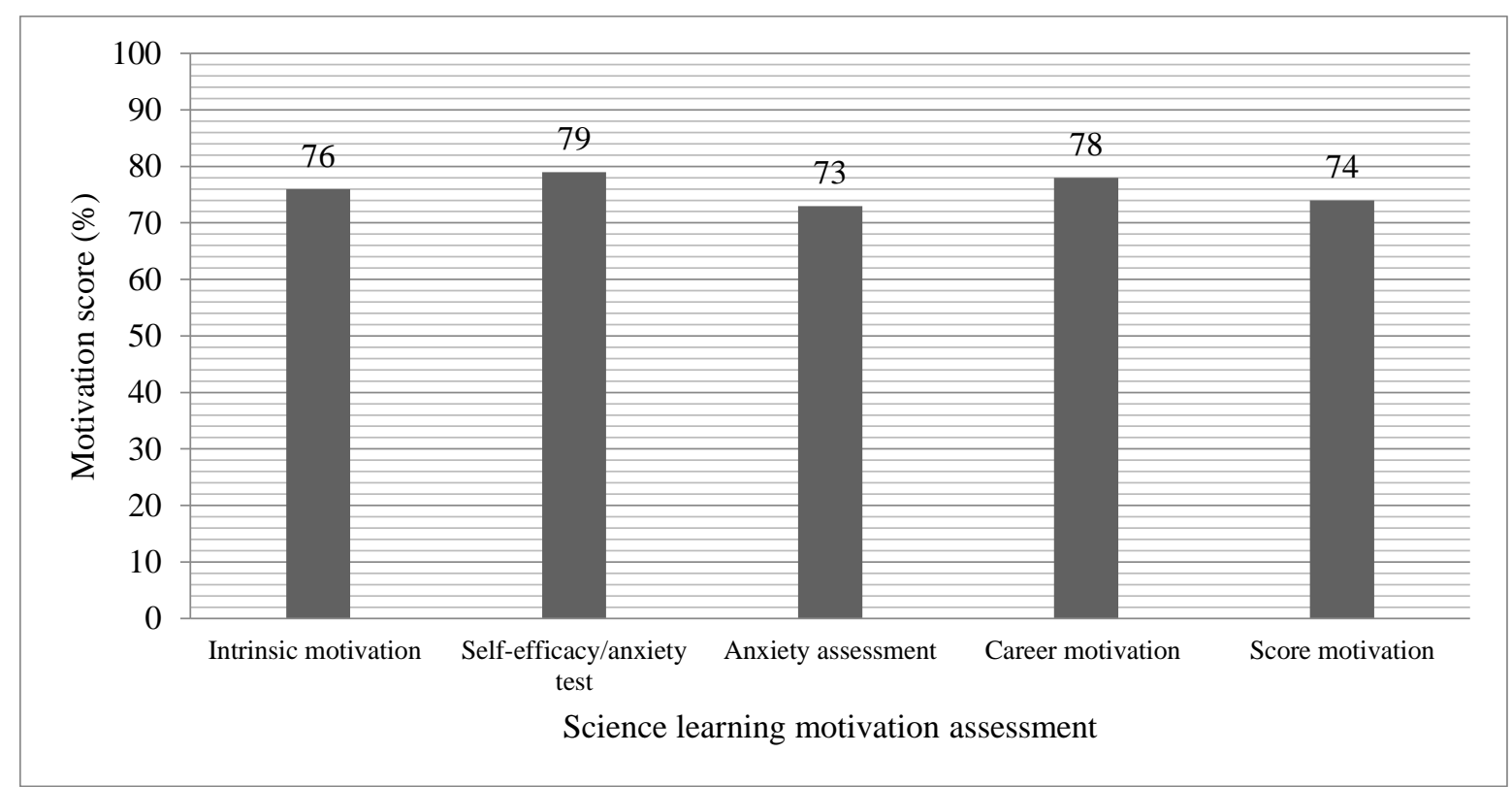

Figure 2. Students' learning motivation assessment on science class

The presented results of the overall learning motivation questionnaire show the highest number of scores on the assessment in intrinsic motivation/personal relationships consisting of 10 questions. The self-efficacy/ anxiety tests involved 9 questions. Anxiety assessment consisted of 4 questions. While two questions were for career motivation, and 5 questions were for motivation value. 
Figure 2 illustrates both intrinsic and extrinsic motivation aspects to measure. The intrinsic motivation has more influence on science learning motivation, especially for the aspect of the self-efficacy/anxiety test aspect. It can be seen from the high average score of 79. Career motivation which is one of the extrinsic motivations, also does show a good impact on science learning motivation with a total score of 78 . This shows that students are motivated to learn science as they can be influenced by both internal and external factors. The average score of this aspect is 76, which is considered a good level or category.

It is confirmed that the implementation of the STEM-based student worksheet in the entrepreneurship lesson can bring good impacts on students' motivation to learn science. Using the STEM-based student worksheet that focuses on the concepts of chemistry and physics, the students are well-motivated in learning science during the entrepreneurship class. It is precisely on the model of the salt-producing tool with a sunlight-collecting mirror. An appropriate and enjoyable learning atmosphere encourages students to get more active and to increase their learning motivation. Likewise, Susanti (2020) expresses that arousing student motivation can be done by designing an appropriate learning process. It automatically becomes an intermediary in stimulating students to try, to working hard, to be diligent as well as to achieve the desired goals.

Students' interest in learning indeed becomes a very positive aspect of improving their learning motivation and creativity in science (Afriana et al., 2016). Furthermore, Sari et al. (2016) state that the increase of learning motivation is always affected by the learning process, which focuses on students. For instance, it can be done by giving them project assignments. On the other study, Wicaksono et al. (2018) show that the students' motivation in learning science influences student achievement. Then, the competence and mastery of science can be further learned through any learning process in which science is included. Intrinsically motivated students will learn more actively because of the internal encouragement in achieving the expected goals. Pradilasari et al. (2019) claim that the low scores obtained by students are just because the students do not either pay enough attention or focus on the learning process. It is also the consequence of the lack of learning motivation. In short, the learning outcomes improvement can be influenced by learning motivation.

The improvement of learning motivation on science can also be seen from changes in the tested score of students both pre-test and post-test. The assessment of learning outcomes was obtained by using test questions, both pre-test and post-test. It included the score of pre-test, 
post-test, and $\mathrm{N}$-gain, which were aimed at finding out the increase in learning outcomes. It was also used to see the differences in the students' average ability at the beginning of the STEM-based student worksheet implementation in the entrepreneurship class as well as at the end of the project. For further details, the assessment of learning outcomes can be seen in Figure 3.

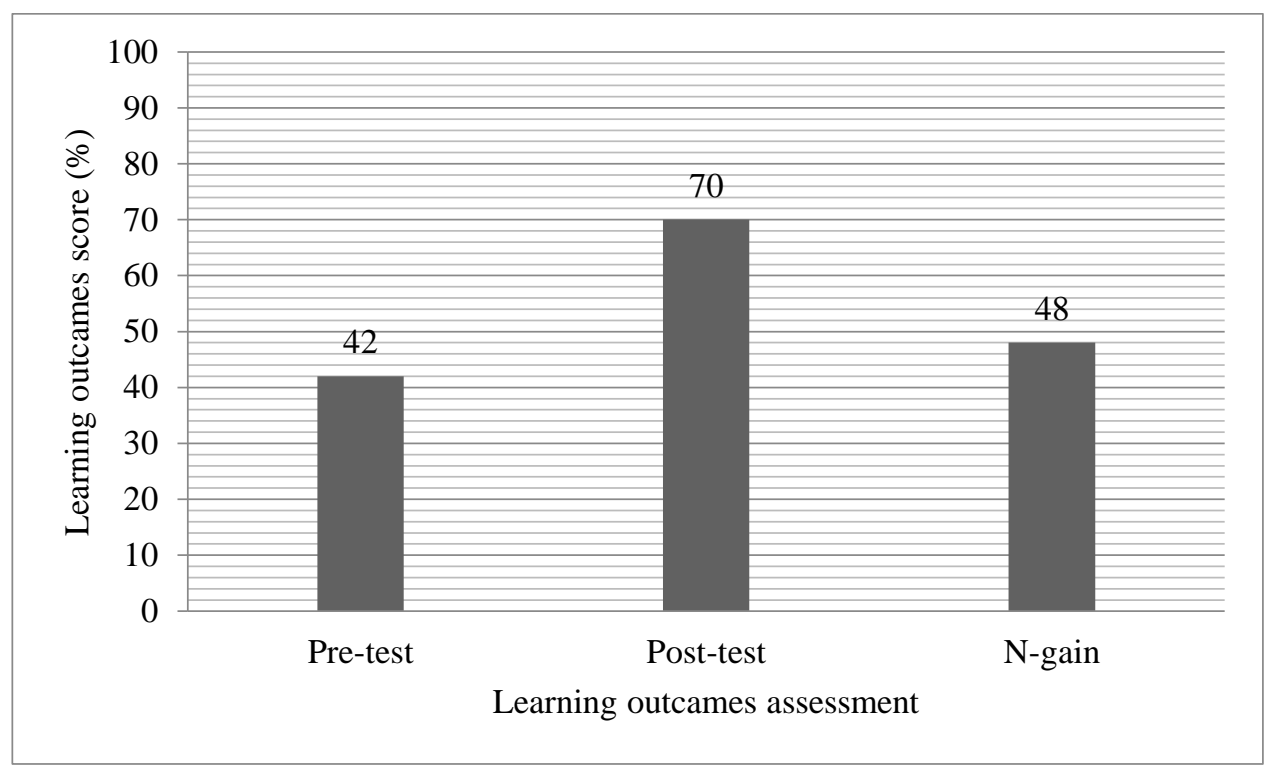

Figure 3. The average score of pre-test, post-test dan N-gain

Figure 3 illustrates the changes in average scores before and after implementing the STEM-based student worksheet in the entrepreneurship class. It provides us with the high differences between the post-test score and the pre-test. The average percentage of pre-test and post-test is considered at a fair level or category with scores of 42 and 70 . Those learning outcomes changes can be interpreted as positive improvements after the teaching and learning process. The highest score of the written pre-test done by students responding to the 20 multiple-choice questions is 55 . Otherwise, the lowest score is 25 , with $42 \%$ of students achieving the passing grades. While the highest score obtained in the post-test is 100 and the lowest is 40 with a completeness level of $70 \%$. The criteria for learning outcomes can be obtained by calculating the $\mathrm{N}$-gain in which the score is 48 as categorized in the medium level.

Saptarini et al. (2019) stated that escalating student completeness scores could be correlated with the role of the STEM-based student worksheet. The STEM positive effects on its implementation can be identified through 3 criteria, namely STEM learning outcomes, type of school, and the way of STEM implementation. Furthermore, Fitriani et al. (2016) show the same result on students' learning outcomes which can be improved by implementing quality 
student worksheets. Then, it allows students to understand the concept of learning well. Darmawan et al. (2018) state that students' group learning activities in the entrepreneurship class increase the completeness of classifications both pre-test as well as post-test.

The STEM-based student worksheet combines several scientific principles related to daily life, especially the process of salt production using a sunlight-collecting mirror. The STEMbased student worksheet integrates the concepts of chemistry and physics in the students' learning activities. The presented chemistry concepts are about salt and its production process assisted by sunlight. At the same time, the physics concept is linked to light regarding the principle of light reflection and the nature of concave mirrors. Yulianti et al. (2018) inform that the concept of achievement in physics is used as an individual ability to understand the scientific process as well as to obtain meaningful scientific information.

In short, those descriptions bring a brief conclusion that the entrepreneurship class can also be linked to science concepts, especially chemistry and physics. One alternative way to link the two concepts is by implementing the STEM-based student worksheet to produce an innovative model of useful products. Producing salt through a sunlight-collecting mirror is such a concrete example. Also, it can be briefly concluded that students' learning outcomes are also influenced by the students' learning motivation.

\section{Students' Creativity Assessment}

Students' creativity assessment of this study was conducted based on the students' activities during the whole learning process of the entrepreneurship class by implementing the STEM-based student worksheet. The observers in each group assessed the learning process. The creativity assessment questionnaire was adapted from the research instruments conducted by Cuenca et al. (2016), which contained ten statements. It consisted of 4 assessment aspects, namely generating ideas, critical thinking, synthesizing/rearranging, and being creative in solving problems. Each aspect of the assessment has a rating scale of 1 to 4 , with the criteria on each scale.

A review of the assessment conducted by observers on various aspects of the creativity in the five groups illustrates which aspects of creativity students achieve the highest score. Sukarso et al. (2019) explain that creative students will discover something new even from existing things. Likewise, Kenedi (2017) states that one's creativity illustrates the flexibility and fluency in thinking and interacting with others and surrounding environments. Those can 
optimally elaborate on the emerging ideas to create an innovative product with new models and new ways that are considered useful for themselves or others.

The average percentage concluded on various aspects of creativity are illustrated in Figure 4. Overall, these results indicate that the average assessment of creativity is in a good category.

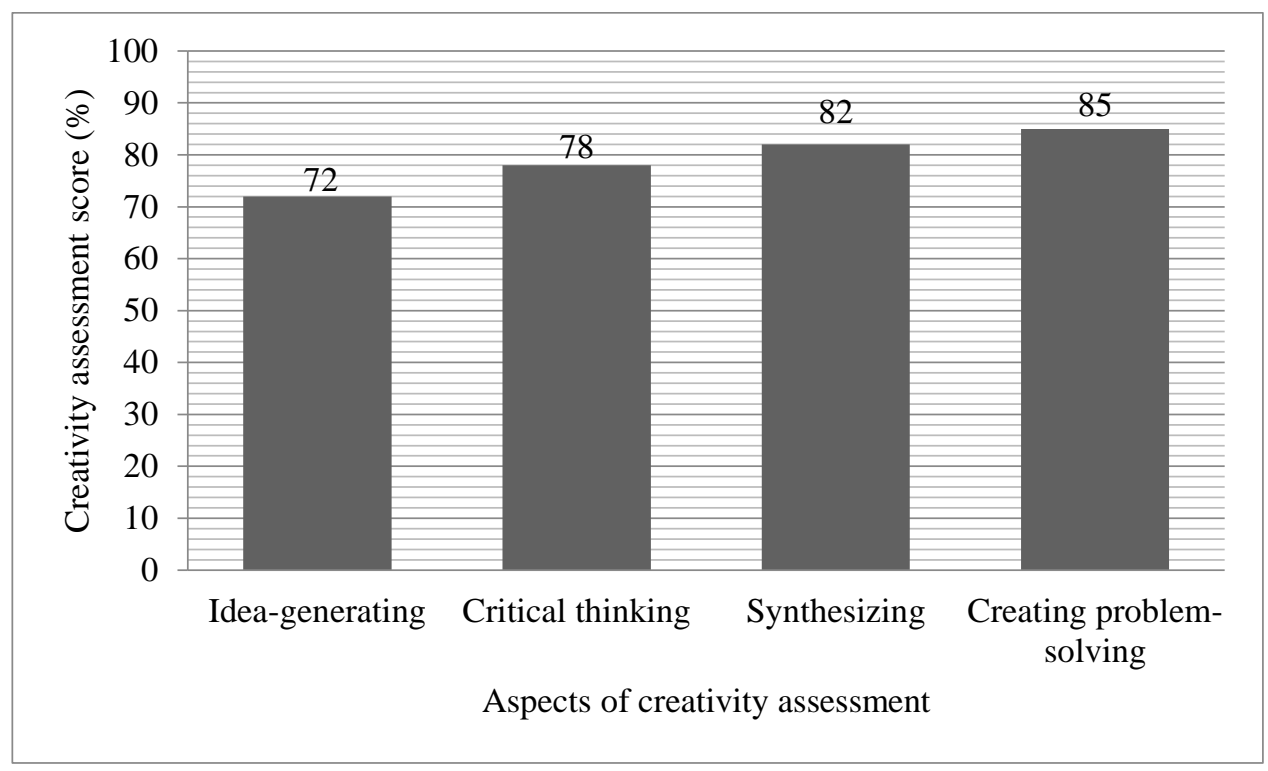

Figure 4. Students' Creativity Assessment

In Figure 4, the highest score in the creativity aspects is creative in solving problems. It was calculated by using a percentage formula as well as comparing the table of creativity assessment category to determine what categories were obtained. Therefore, the average percentage is $79 \%$ for the overall categories. Thus, it is classified as a good category. These results indicate that students have been able to develop their creative ideas in the form of making the salt-producing tools using a mirror to collect sunlight during the implementation of the STEM-based student worksheet in the entrepreneurship class.

Student creativity can be developed by providing them with the problems set in the STEMbased student worksheet. The presented problems will develop students' ability to find the proper solution by thinking critically and re-synthesizing the collected data or information to generate new creative ideas in solving those problems. The final result of this process will be an innovative product in the form of salt-producing tools using a sunlight-collecting mirror. This tool will be presented by each group.

In line with those explanations above, the research of Madyani et al. (2019) finds that integrated science learning can be used to develop creativity, critical thinking, and scientific attitudes of students. Moreover, Lestari et al. (2018) explain that STEM-based learning 
presents problems and questions that encourage students to develop their ability to assume information so that the learning process will strongly support students to think critically. In another study, Wardi (2013) suggested that the development of students' creativity should be done as early as possible so that they are accustomed and trained to develop entrepreneurial characters. Then, they are ready to compete in the workforce of either the government or private sectors.

The development of students' creativity provides opportunities to show valuable ideas to create a learning atmosphere that can improve students' sensitivity to support a comfortable and exciting learning environment (Kenedi, 2017). Another opinion was also raised by Ambrose (2017), creativity is not only related to the creations of arts and products but also related to science, engineering, innovative thinking, and problem-solving skills. Similarly, Sambada (2012) described the level of students' creativity provides significant roles to problem-solving skills while students are participating in learning activities.

Creativity is one of the psychomotor aspects that is applied to nowadays learning process. Therefore, the STEM-based student worksheet is the approach that has been developed together into the entrepreneurship class to support the development of creativity in the learning process. The explicit purpose is to make a salt-producing tool using a sunlightcollecting mirror. Thus, the implementation of the STEM-based student worksheet is in accordance with the development of students' creativity as it integrates the concepts of science, technology, engineering, and mathematics at once.

The results of the assessment on various aspects of creativity in each group of grade X IPA 1 can be seen through the products. Furthermore, the perfect finished products which indicate students' creativity can be directly seen through these provided Figures 5.

The salt-producing tools using a sunlight-collecting mirror are students' creativities as they were designed and created as attractive as possible by each group. Through the product evaluation questionnaire, the created products were evaluated by the observer using a rating scale of 1 to 4 . The product assessment instrument was adapted and modified from the product assessment forms of the Indonesian national syllabus of entrepreneurship subjects. 


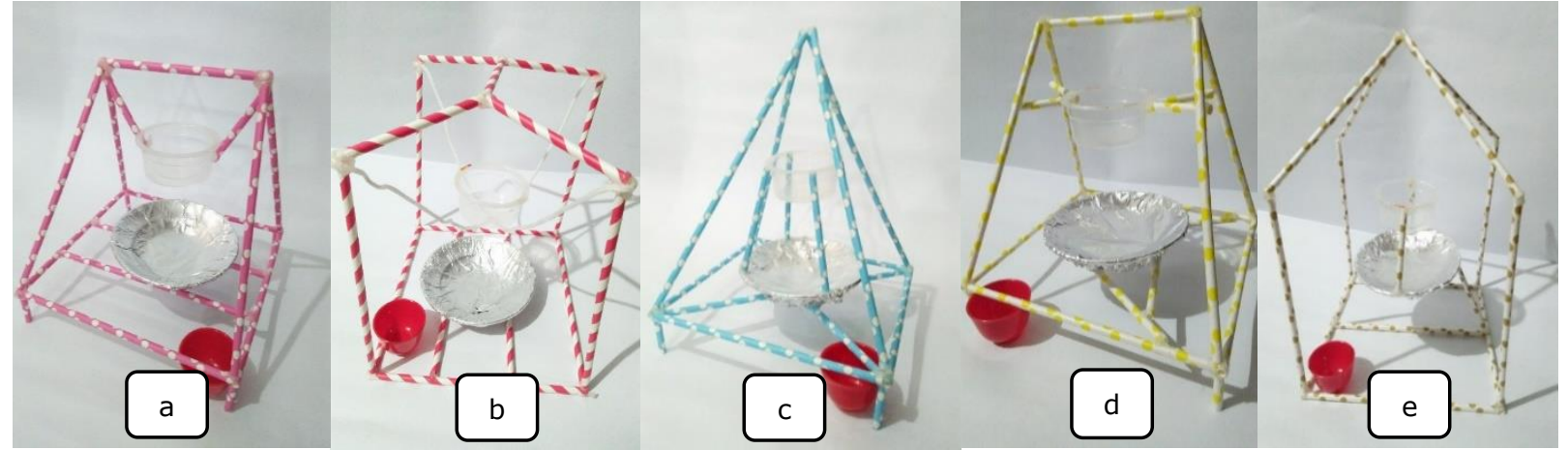

Figure 5. Products of students' creativity in PKWU class taught using the STEM-based student worksheet: (a) Group 1, (b) Group 2, (c) Group 3, (d) Group 4, (e) Group 5.

The instrument to assess the salt-producing tools integrated with sunlight-collecting mirrors was set based on four aspects of assessment. They are physical appearance, parts of the tool model, creativity, and material selection. The average product rating results are presented in Figure 6.

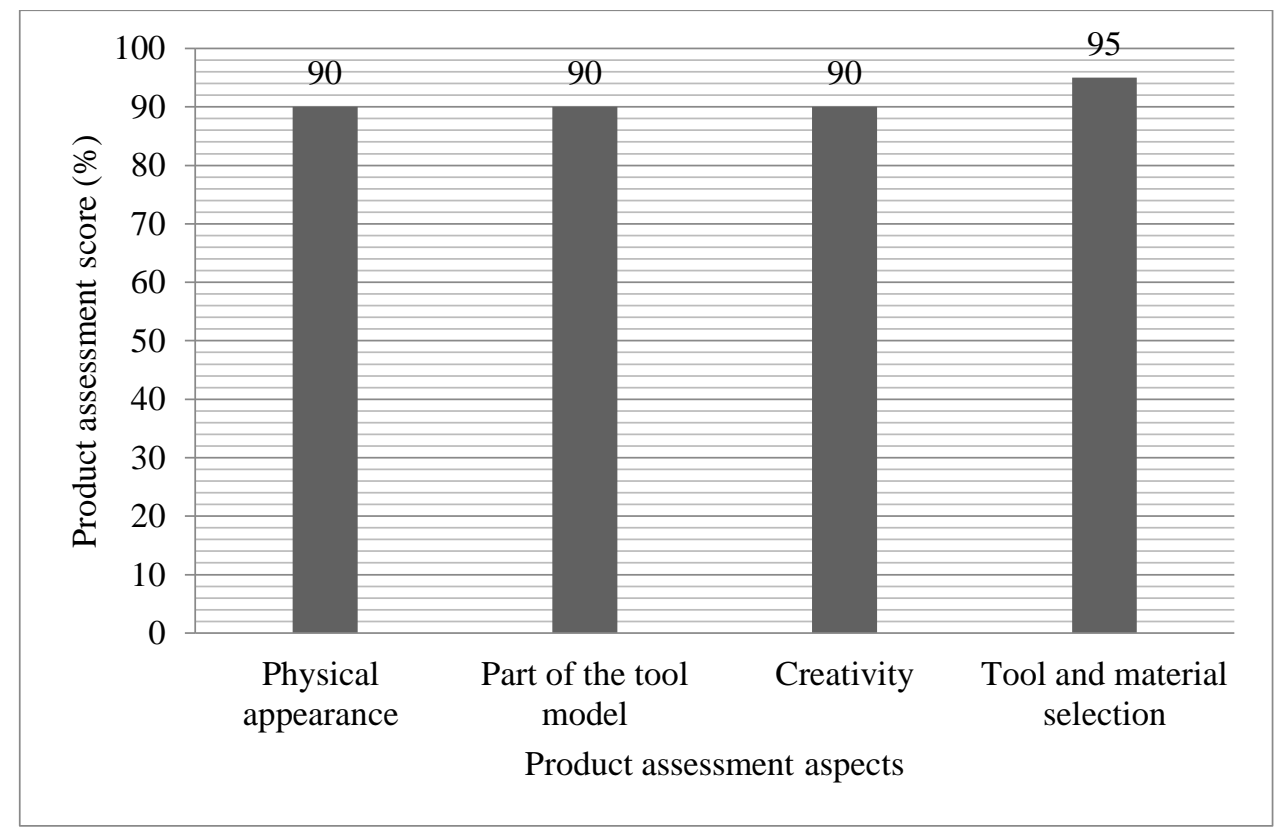

Figure 6. Students' product assessment

Figure 6 illustrates that the product assessment of students' designs is considered very good, with an average percentage of $91 \%$. It also shows that the entrepreneurship lesson using the STEM-based student worksheet can empower students' skills t create good products using student skills. Syukri et al. (2013) state that new ideas encourage students to observe and look for additional information related to the topic being discussed.

The initial needs analysis data showed that the learning process was only limited to in the form of lectures delivered by the teacher all this time. It showed a lack of students' scientific 
skills development in making innovative products. Thus it is considered as one of the aspects which lead to the underdeveloped skills of students. In line with those explanations above, Ali et al. (2019) state that the development of an innovative product with local wisdom could sharpen students' skills in using technology, developing creativity, thinking critically, and increasing knowledge about various concepts of local wisdom. Similarly, Sukarso et al. (2019) illustrate that the application of appropriate teaching methods will influence the process and the creation of innovative products, even if they use something that already exists. The process of combining resources in the surrounding environment through new creative and innovative ways is the essence of entrepreneurship in creating a different external value for the market of the product (Purbaningrum, 2016).

\section{Conclusion}

Based on the results and discussion of the study, it can be concluded that the STEM-based student worksheet, which was developed in the form of salt-producing tools using a sunlightgathering mirror. This student worksheet could be used as teaching materials in the entrepreneurship class. The STEM-based student worksheet implementation that was developed could significantly increase students' learning motivation and creativity. The product evaluation model of salt-producing tools using a sunlight-collecting mirror produced by students showed an average value of a very good percentage. It was all done by implementing the STEM-based student worksheet.

\section{References}

Adlim, M., Hanum, L., \& Toa, A. A. M. (2015). Developing chemistry practicum module with science, technology, engineering, and mathematics approach: Proceedings of the 5th Annual International Conference Syiah Kuala University (AIC Unsyiah) 2015 In conjunction with the 8th International Conference of Chemical Engineering on Science and Applications (ChESA) 2015, September 9-11, 2015, Banda Aceh, Indonesia.

Adlim, M., Rusydi, N., \& Nurmaliah, C. (2018). The effect of conventional laboratory practical manuals on preservice teachers' integrated science process skills. Journal of Turkish Science Education, 15(4), 116-129.

Afriana, J., Permanasari, A., \& Fitriani, A. (2016). Penerapan project learning terintegrasi STEM untuk meningkatkan literasi sains siswa ditinjau dari gender. Jurnal Inovasi Pendidikan, 2(2), 202-212.

Ali, A. Nawidi, M. F., Nurusshobah., \& Sadiah, S. D. (2019). Chemistry learning based on kibas asah module (wetland-based chemistry) integrated AR-sparkol on buffer solution material: students' cognitive and motivation diagnostic, Scientiae Educatia: Jurnal Pendidikan Sains, 8(1), 103-118. 
Ambrose, D. (2017). Interdisciplinary invigoration of creativity studies. The Journal of Creative Behavior, 51(4), 348-351.

Ariani, L., Sudirman., \& Nurhayati, S. (2019). Analisis berpikir kreatif pada penerapan problem based learning berpendekatan sciences, technology, engineering and mathematics. Jurnal Inovasi Pendidikan Kimia, 3(1), 2307-2317.

Arikunto, S. (2013). Manajemen Penelitian. Jakarta: Rineka Cipta.

Chadarisman, A., Hantoro, R., \& Sarwono. (2012). Studi eksperimental rancang bangun system desalinasi tenaga surya menggunakan solar reflector untuk produksi brine pada $25^{\circ}$ Be. Jurnal Teknis Pomits, 1(1), 1-4.

Cuenca, L., Alarcon, F., Boza, A., Diego, M. F., Ruiz, L., Gordo, M., Poler, R. \& Alemany, M. M. E. (2016). Rubric to assess the competence of innovation, creativity and entrepreneurship in bachelor degree. Brazillian Journal of Operations \& Production Management, 13(1), 118-123.

Darmawan, D., Gitakarma, M. S., \& Nugraha, N. P. (2018). Penerapan model kooperatif STAD untuk meningkatkan hasil belajar prakarya dan kewirausahaan siswa kelas X SMA. Jurnal Pendidikan Teknik Elektro Undiksha, 7(3),123-133.

Fitriani, Hasan, M., \& Musri. (2016). Pengembangan lembar kegiatan peserta didik (LKPD) berbasis masalah untuk meningkatkan pemahaman konsep dan aktivitas belajar peserta didik pada materi larutan penyangga. Jurnal Pendidikan Sains Indonesia, 4(2), 24-35.

Glynn, S., Taasoobshirazi, G., \& Brickman, P. (2009). Science motivation questionnaire: construct validation with nonscience majors. Journal of Research Science Teaching, 46(2), 127-147.

Hasan, R., Lukitasari, M., Darmayani, O., \& Santoso, S. (2019). The Variation pattern of cooperative learning models implementation to increase the students creative thinking and learning motivation. Journal of Physics: Conference Series, 1157 (022075). IOP Publishing.

Kenedi. (2017). Pengembangan kreativitas siswa dalam proses pembelajaran di kelas II SMP Negeri 3 Rokan IV Koto. Jurnal Ilmu Pendidikan Sosial, Sains dan Humaniora, 3(2), 329347.

Khoiriyah, N., Abdurrahman, \& Wahyudi, I. (2018). Implementasi pendekatan pembelajaran stem untuk meningkatkan kemampuan berfikir kritis siswa SMA pada materi gelombang bunyi. Jurnal Riset dan Kajian Pendidikan Fisika, 5(2), 53-62.

Kurniawan, F. A. (2017). Pengaruh pembelajaran berbasis Web terhadap motivasi dan hasil belajar siswa kelas X SMA Negeri Paguyangan pada mata pelajaran fisika pokok bahasan suhu dan kalor, Scientiae Educatia: Jurnal Pendidikan Sains, 6(1), 1-7.

Lestari, D. A. B., Astuti, B., \& Darsono. (2018). Implementasi LKS dengan pendekatan STEM (sciences, technology, engineering and mathematics) untuk meningkatkan kemampuan berfikir kritis siswa. Jurnal Pendidikan Fisika dan Technology, 4(2), 202-207.

Madyani, I., Yamtinah, S., \& Utomo, S. B. (2019). Profile of creative thinking skill on junior high school students in science learning by gender, Scientiae Educatia: Jurnal Pendidikan Sains, 8(2), 119-130.

Mahyuna, M., Adlim, M., \& Saminan, I. (2018). Developing guided-inquiry-student worksheets to improve the science process skills of high school students on the heat concept. Journal of Physics: Conference Series, 1088 (012114). IOP Publishing. 
Maulana, K. D., Jamil, M. M., Putra, P. E. M., Baiti., Rohmawati, \& Rahmawati. (2017). Peningkatan kualitas garam bledug kuwu melalui proses kristalisasi dengan pengikat pengotor $\mathrm{CaO}, \mathrm{Ba}(\mathrm{OH})_{2}$, dan $\left(\mathrm{NH}_{4}\right)_{2} \mathrm{CO}_{3}$. Journal of Creavity Student, 2(1),42-46.

Mukhlis. (2017). Pembelajaran model problem solving materi stoikiometri pada mata kuliah kimia dasar I untuk meningkatkan motivasi, keterampilan generik sains dan pemahaman konsep mahasiswa. Jurnal IPA dan Pembelajaran IPA, 1(1), 171-181.

Mustain, L., \& Herlina, Y. (2019). STEM for establishing energy literacy in maritime vocational education. Scientiae Educatia: Jurnal Pendidikan Sains, 8(2), 131-140.

Pradilasari, L., Gani, A., \& Khaldun, I. (2019). Pengembangan media pembelajaran berbasis audio visual pada materi koloid untuk meningkatkan motivasi dan hasil belajar siswa SMA. Jurnal Pendidikan Sains Indonesia, 7(1),9-15.

Purbaningrum, C. W. D. (2016). Pengembangan model pembelajaran prakarya dan kewirausahaan dengan prinsip the great young entrepreneur di SMK untuk kurikulum 2013. Jurnal Pendidikan Vokasi, 6(1), 15-23.

Putri, Y., Gloria, R.Y., \& Mulyani, A. (2018). The effectiveness of bioentrepreneurship learning using comics on the sub-concepts angiosperms for high school students, Scientiae Educatia: Jurnal Pendidikan Sains,7(2), 159-172.

Quang, L. H., Hoang, V. D., Chuan, N. T. T., Anh, N. H., Nam, \& Nhung, V.T. H. (2015). Integrated science, technology, engineering and mathematics (STEM) education through active experience of designing technical toys in Vietnamese schools. British Journal of Education, Society \& Behavioural Science, 11(2), 1-12.

Rahmiza, S., Adlim, \& Mursal. (2015). Pengembangan LKS STEM (science, technology, engineering dan mathematics) dalam meningkatkan motivasi dan aktivitas belajar siswa SMA Negeri 1 Beutong pada materi induksi elektromagnetik. Jurnal Pendidikan Sains Indonesia, 3(1), 239-250.

Sukarso, S., Widodo, A., Rochintaniawati, D., \& Purwianingsih. (2019). The potential of students' creative disposition as a perspective to develop creative teaching and learning for high school biological science. Journal of Physics: Conference Series, 1157 (022092). IOP Publishing.

Sambada, D. (2012). Peranan kreativitas siswa terhadap kemampuan memecahkan masalah fisika dalam pembelajaran konstektual. Jurnal Pendidikan Fisika dan Aplikasinya, 2(2),3747.

Saptarani, D., Widodo, A., \& Purwianingsih, W. (2019). Biology teachers and high school student perceptions about STEM learning. Journal of Physics: Conference Series, 1157 (042007).

Sari, R. P., Adlim, M., \& Gani, A. (2018). STEM learning in reguker and vocational high schools on the topic of scientific menu card fabrication. Journal of Physics: Conference Series, 1088 (012114).

Sari, V. A., Adlim, \& Mustanir. (2016). Implementasi praktikum berbasis proyek untuk meningkatkan motivasi dan hasil belajar peserta didik pada materi hidrolisis garam kelas XI SMAN 1 Unggul Darul Imarah. Jurnal Pendidikan Sains Indonesia, 4(2), 84-88.

Setiawan, M. E., \& Indriwati, S. E. (2018). The implementation of quantum teaching (QT) and think talk write (TTW) through lesson study to improve students' learning motivation, Scientiae Educatia: Jurnal Pendidikan Sains, 7(1), 79-92. 
Susanti, L. (2020). Strategi Pembelajaran Berbasis Motivasi. Jakarta: Alex Media Komputindo.

Susanti, L. Y., Hasanah, R., \& Khirzin, M. H. (2018). Penerapan media pembelajaran kimia berbasis sciences, technology, engineering and mathematics (STEM) untuk meningkatkan hasil belajar siswa SMA/SMK pada materi reaksi redoks. Jurnal Pendidikan Sains, 6(2), 32-40.

Syukri, M., Halim, L., \& Meerah, T. S. (2013). Pendidikan STEM dalam entrepreneurial science thinking "EScIT": satu perkongsian pengalaman dari UKM untuk aceh: Proceeding of Aceh Development International Conference (ADIT), Kuala Lumpur, Malaysia.

Trikobery, J., Rizal, A., Kurniawan, N., \& Zuzy, A. (2017). Analisis usaha tambak garam di desa pengarengan kecamatan pangenan kebupaten Cirebon. Jurnal Perikanan dan Kelautan, 8(2), 168-175.

Wardi, R. (2013). Motivasi, prestasi belajar, dan pelatihan kerja kaitannya terhadap kreativitas siswa. Jurnal Ekonomi Pendidikan dan Kewirausahaan, 1(2),163-176.

Wicaksono, A. G. H., Minarti, I. B., \& Roshayanti, F. (2018). Analysis of students' science motivation and nature of science comprehension in middle school. Indonesian Journal of Biology Education, 4(1), 35-42.

Yulianti, L., Parno., Yogismawati, F., \& Nisa, I. K. (2018). Building scientific literacy and concept achievement of physics through inquiry-based learning for STEM education. Journal of Physics: Conference Series, 1097 (012022). 